THE LANGUAGE OF LITERATURE

General Editor: N. F. Blake

Professor of English Language and Linguistics

University of Sheffield 


\section{THE LANGUAGE OF LITERATURE}

\section{General Editor: N. F. Blake}

Professor of English Language and Linguistics, University of Sheffield

\section{Published titles}

An Introduction to the Language of Literature

The Language of Shakespeare

The Language of Chaucer

The Language of Wordsworth and Coleridge

The Language of Irish Literature

The Language of D. H. Lawrence

The Language of Thomas Hardy

The Language of Drama

The Language of Jane Austen

The Language of the Metaphysical Poets

The Language of James Joyce

The Language of Twentieth-Century Poetry

The Language of George Orwell

The Language of Old and Middle English Poetry
N. F. Blake

N. F. Blake

David Burnley

Frances Austin

Loreto Todd

Allan Ingram

Raymond Chapman

David Birch

Myra Stokes

Frances Austin

Katie Wales

Lesley Jeffries

Roger Fowler

G. A. Lester

\section{Series Standing Order (The Language of Literature)}

If you would like to receive future titles in this series as they are published, you can make use of our standing order facility. To place a standing order please contact your bookseller or, in case of difficulty, write to us at the address below with your name and address and the name of the series. Please state with which title you wish to begin your standing order. (If you live outside the United Kingdom we may not have the rights for your area, in which case we will forward your order to the publisher concerned.)

Customer Services Department, Macmillan Distribution Ltd

Houndmills, Basingstoke, Hampshire RG21 6XS, England 


\title{
An Introduction to the Language of Literature
}

\author{
N. F. BLAKE
}




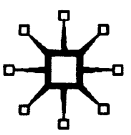

C N. F. Blake 1990

All rights reserved. No reproduction, copy or transmission of this publication may be made without written permission.

No paragraph of this publication may be reproduced, copied or transmitted save with written permission or in accordance with the provisions of the Copyright, Designs and Patents Act 1988, or under the terms of any licence permitting limited copying issued by the Copyright Licensing Agency, 90 Tottenham Court Road, London W1T 4LP.

Any person who does any unauthorised act in relation to this publication may be liable to criminal prosecution and civil claims for damages.

The author has asserted his right to be identified as the author of this work in accordance with the Copyright, Designs and Patents Act 1988.

Reprinted 1991, 1994

Published by

PALGRAVE

Houndmills, Basingstoke, Hampshire RG21 6XS and 175 Fifth Avenue, New York, N. Y. 10010

Companies and representatives throughout the world

PALGRAVE is the new global academic imprint of

St. Martin's Press LLC Scholarly and Reference Division and Palgrave Publishers Ltd (formerly Macmillan Press Ltd).

ISBN 978-0-333-45411-4 ISBN 978-1-349-21101-2 (eBook)

DOI 10.1007/978-1-349-21101-2

This book is printed on paper suitable for recycling and made from fully managed and sustained forest sources.

A catalogue record for this book is available from the British Library.

$\begin{array}{llll}10 & 9 & 8 & 7\end{array}$

$\begin{array}{lllll}06 & 05 & 04 & 03 & 02\end{array}$ 


\section{Contents}

Preface

Introduction $\quad 1$

1 Sentence Structure 11

2 Group Structure: The Noun Group 22

3 Group Structure: The Other Groups 36

4 Vocabulary 51

5 Sounds and Patterns $\quad 69$

6 Pragmatics and Literary Texts 83

7 Cohesion 104

8 Conclusion 122

Notes 145

Suggestions for Further Reading 146

Index 148 


\section{Preface}

In common with the other volumes in the series, this book attempts to explain style in terms which do not presuppose too extensive an acquaintance on the part of the reader with linguistic terminology. In some ways this volume provides the background for many of the others which have appeared or will appear in the series since it is a basic guide to style. Its orientation is not basically theoretical; it attempts to provide help in a pragmatic way for those who recognise the importance of language in literature, but who do not know where to start or how to exploit the particular knowledge and skills they possess. It is hoped that the book will be accessible not only to undergraduates on English and other courses, but also to sixth-formers preparing for the new A level English Language exams. Individual chapters have been delivered in modified forms as lectures to audiences in Britain and elsewhere in Europe. I am grateful to them for their comments and help. An earlier form of the introduction appeared in Revista Alicantina de Estudios Ingleses 1 (1988), and I am grateful to its editor for permission to re-use some of that material here.

I have thought it helpful to use mostly the same passages for the various chapters since most readers will be tackling an individual piece of literature in the same way, though there is some variety in the choice of work discussed. I acknowledge permission from Faber \& Faber to reproduce the poem, 'This Lunar Beauty', by W. H. Auden.

I would like to thank Barbara Flather and Kath Keegan for their patience and help in the preparation of the typescript. 